\title{
S/words versus S/words: A Bidirectional Reading of the Post/colonial Fictions
}

\author{
* Saleem Akhtar Khan, Head / Assistant Professor (Corresponding Author) \\ ** Muhammad Ehsan, Visiting Faculty \\ *** Nasar Iqbal, Lecturer
}

\begin{abstract}
The article explicates the polemical schema of the novels produced by the British and the Indian writers apropos the historical event of the anticolonial rebellion/ revolution (1857). Grounded in the idea of creating a dialogue between the colonial and counter discursive texts, the research invokes Richard Lane's bidirectional approach to explain how conflictual political visions trigger the skewed versions of the great defiance. The novelists of both nations have produced prolific fictional yields to represent the epic event. However, keeping in mind the scope of the study, the researchers have delimited their focus upon two of the representative novels, one for each nation: Louis Tracy's The Red Year: A Story of the Indian Mutiny (1907) for the English version and Basavaraj Naikar's The Sun behind the Cloud (2001) for the Indian one. Each of the novels voices the sloganized rhetoric of the respective nation while narrating the colossal clash, that is, Tracy portrays the mutiny as nefarious recalcitrance of the Indian rebels to disrupt the civilizational program and Naikar presents it as an auspicious act of defiance against the exploitative encroachment of the usurpers. A comparison has been drawn between the ideology-ridden discursive patterns of both the belligerent narratives and an intriguing concatenation of the diametric contrasts has been identified. The essential argument of the article is entrenched in the postcolonial and the new historicist notions vis$\grave{a}$-vis the chequered nature of the textual narratives and politicized parlance of the discursive records of the historical happenings.
\end{abstract}

Keywords: Bidirectional Reading, Polemical Fiction, Anticolonial Resistance

Introduction

The narration of the past is a complex process of textualization of actualities that aims, or at least claims, to portray and preserve the historical happenings. But this process of narration is influenced by many factors ranging from the personal preferences of the writers to the contextual pressures and the national choices. Especially, the fictional narratives are more fickle as they overtly fabricate under the pretext of imaginative freedom. Due to these portmanteau problematic representational valences, the produced vicarious versions are marked by incongruities, contrasting claims, lopsidedness, and so on. Framed in the context of solipsistic scenarios, a narrative "entails ontological and epistemic choices with distinct ideological and even specifically political implications" (White, 1987, p. ix). Therefore, the textual records become the intriguing labyrinths where actual details founder in the realm of discursive gimmickry.

The study approaches two fictional narratives about an event in colonial history, the anticolonial revolution of 1857 in India (the pre-partition India includes both Pakistan and Bangladesh). The revolution is one of the prominent landmarks in the nineteenth-century colonial history that challenged the imperial center, England, and shook its pivot. It has put an unmistakable mark on the consciousness of both the colonizer and the colonized. Due to its overarching impact, it has become an acclaimed trope among the literary writers across the borders and inspired an array of fictional narratives. Resultantly, a full-fledge sub-genre of the fictional narratives has evolved under the title of Mutiny Fiction. For this study, two novels have been taken from the rich repository to represent the conflictual stances of the English and the Indian regarding the revolution: Louis Tracy's The Red Year: A Story of the Indian Mutiny (1907) and Basavaraj Naikar's The Sun behind the Cloud (2001). Tracy is the Victorian novelist whose work has been recognized by Patrick Brantlinger (1988), Gautam Chakravarty (2004), and Shailendra Singh (1973). Naikar, the Indian novelist, has

* Department of English, University of Sialkot, Sialkot Email: saleemniazee@ gmail.com

** Department of English, University of Narowal, Narowal Email: ehsanlitterateur@gmail.com

*** Department of English, University of Narowal, Narowal Email: nasariqbal777@gmail.com 
also received critical appreciation from M.A. Jeyaraju (2006), Singha (2006), Sarangi (2008), Chandra and Prasad (2010), and Chittaranjan Misra (2016). Both the writers have toed, predominantly, the official national standpoints concerning the status and details of the revolution/rebellion.

Tracy's The Red Year (1907) is an English novel that presents the colonizers' perspective on the issue. Focalizing the herculean journey of the English hero, Frank Malcolm, Tracy narrates the gory encounters between the Indian mutineers, as he prefers to call them, and the English soldiers from Meerut to Delhi. The prototypical English protagonist manages simultaneously the romantic demands and the national duties in the perilous predicament. His crusade has won him the national laudation, religious commendation, and moral exaltation. The fictional representation parallels the official stance of the English regarding the various aspects of the Mutiny and the narration is visibly lopsided. Moreover, to give his narrative the realistic semblance, he keeps on referring to the historical archives (p. 21, 50, 76). The novel appropriately embodies the national sentiments, ideological predilections, and orientalist conceptions. Whereas, Basavaraj Naikar's The Sun behind the Cloud (2001) is an Indian novel in English that voices the stance of the colonized nation. The narrative revolves around the resistance of the king of Naragund, Bhaskararao Bhave. The tragic figure of the protagonist parallels, according to the writer himself, "Okonkwo of Chinua Achebe's Things Fall Apart" (Naikar, 2001, p. viii). He fights heroically against the British colonial avantgarde, the East India Company. Though his efforts fail to bring fruition, he towers due to the moral uprightness and vigor with which he resists the unlawful usurpation. In his prefatory note, Naikar claims to have managed adherence to the archival details by narrating the events "realistically without resorting to sentimentalism" (2001, p. viii). Precisely, the narrative is entrenched in the Indian nationalist feelings regarding the crucial landmark in the history of their anti-colonial struggle.

Thus, delimiting focus on these two representative works, the article aims to outline the contrasting textual representations of the happening of revolutionary/mutinous struggle of the Indians against the rule of the East India Company. The researchers take up the questions of authenticity of the narratives, incorporation of the nationalist ideologies, projection of the political priorities, the historicization of textuality, and textualization of history. Through the resolution of these charged questions, the representational schemas and, also, their anchorage in the political goals have been discussed.

\section{Theoretical Framework:}

The critique of the competing fictional versions is theoretically informed by Richard Lane's insights. His 'bidirectional' approach engages with the "agonistic, dialectical, [and] dialogic" (2006, p.19) patterns in the kind of contesting narratives. To accomplish the rigorous analysis, "the new text is [placed] in a more dynamic relationship with that of the old" $(2006,19)$. In his systems of descriptors, "the new" stands for the postcolonial work and "the old" for the colonial one. Here, Jan Mohamed's persuasion for the simultaneous study of these bellicose textual narratives remains relevant: "To appreciate them thoroughly, we must examine them in juxtaposition to domestic English fiction and the anglophone fiction of the Third World" because "This dialogue merits our serious attention" (in Ashcroft et al. 1995, p. 23). Likewise, Edward Said, the doyen in the domain, envisioned the potential of the subject by describing it as "comparative literature of imperialism" (1994, 18). All these theoretical postulates suggest that the politicality of the verbal war is manifest in the "framing of the nature of a particular issue" (Wenden, 2005, 91). This makes the understanding of interfacing of the linguistic representations and nationalist ideologies within texts, either scaffolding colonialism (colonial) or questioning it (postcolonial), indispensable. Informed by these poststructuralist theoretical propositions, the researchers approach the selected texts for the exposition of the latent and the manifest dimensions of discursive maneuvering.

\section{Methodological Design:}

The analysis is a qualitative, textual, and comparative one in its nature. To develop the dialogue between the selected colonial and postcolonial fictions, the researchers have used Jenni Ramone's model of "postcolonial retelling" (2011, p.157) as the methodological design. She has explained her methodological approach through its application upon Conrad and Achebe's canonical novels: Heart of Darkness (1899) and Things Fall Apart (1958). Ramone has contrasted these novels as the prototypical examples of the colonial and counter-discourse respectively. The focus is on the perspectival conflicts and polemical narration by which these combative narratives are marked. Her 
model takes "opposition" (p.33) in narration and description as its pivot. Under the defined modus operandi, the broader narrative schemas of both the novels, the colonial and written back, have been identified and compared to conclude.

By Ramone's methodological benchmark, contrasting positions and polemical perspectives of both the parties, as represented in the selected novels, have been studied through juxtaposition. For this purpose, the competing versions of the following issues have been put vis-à-vis:

i. Issue of legitimacy of colonization

ii. Status of the revolutionary struggle

iii. $\quad$ Characterization of Self and Other

iv. Representation of the spatial dimensions

v. Rhetorical Gimmickry

vi. Religious prejudice

vii. Post-revolution Scenario

All these issues have been discussed concerning the selected novels and the contrasting versions produced by both the writers have been explained to make the belligerent disposition of the politicized narration explicit.

\section{Discursive Politics in (post)colonial context:}

The studies exploring discursivity of the represented realities abound that try to unveil the textual politics pervasive in colonial and postcolonial epistemological paradigms. Kiernan's (1969/2015) is one of the pioneering catalogs of the contrived western archives that specifically focuses on the English colonial expansion and discourse. Expanding the scope of his analysis to various Spatiotemporal domains, he has exposed the political ideologies buttressing the imperialist incursions. He outlines the polymorphous progression of the Europeans into the Asian, African, and American territories parallel to their discursive manipulation to legitimize the criminal encroachment. He concludes his survey of the predicament of the colonized continents on an optimistic note by predicting their awakening, despite the injection of "all the drowsy syrups of the world" (p.230). The strongest among these drowsy doses is the discursive one and the reawakening is supposed to generate the realization of the verbal clutch.

Said's Orientalism (1978/ 1995) remains the most representative of the works among the array of the discursive critiques of the historical records. He has categorically denied the referential nature of the colonial discourse and tagged it as a fantasized set of mere verbal representations that is "not 'truth' but representations" (p. 21). He explains the totalizing orientalist textual corpus as "a system of representations framed by a whole set of forces that brought the Orient into Western learning, Western consciousness, and later, the Western empire" (p. 202-3). Summing up his holistic survey of the myriads of the western texts, he declares them to be merely "ideological fictions" (p. 321) devoid of factuality. The orientalist pretensions of having produced the realistic records have been shattered to show the parochial and prejudiced representational practices. So, Said's magnum opus aptly disrupts the orientalist exploitative tradition cherished for centuries by the western intelligentsia as the parameter for the civilizational analyses.

The lopsided colonial discourse has provoked equally committed discursive retaliations across the colonized and once-colonized societies. Pursuing the reactionary temperament of it, Tiffin (1987) identifies the pivot of the postcolonial consciousness in its "counter-discursive" disposition. She explains the centripetal move of apparently divergent postcolonial literary traditions: "the processes of artistic and literary decolonization have involved a radical dis/mantling of European codes" (p. 17). Thus, the defining pivot of postcoloniality is its epistemological defiance to the metanarratives of the western intellectual paradigm. These charged representational reciprocations bespeak the presence of "a dialectical relationship" (p. 17) between the colonizer and the colonized.

Consequently, the Manichean divide resides at the heart of colonial discourse and postcolonial response. Ramone (2011) has studied the fictional yields corresponding to these discursive categories in the flux of the continuous contentious dialogue between colonizers and colonized. Her prime focus is on the modes being adopted by the postcolonial writers in their practice of deconstructing the canonical colonial fictions. These countering methods vary ranging from the flexible "retelling" (p. 157) to the closely adherent rewriting (p. 169). She exemplifies these counter texts by analyzing Achebe's Things Fall Apart (1958) and Cesaire's A Tempest (1969). In this way, 
the colonial and postcolonial literature creates a constant dialogue that is marked by parochial notions and polemical narrations.

\section{The Raj in Historical and Fictional Narratives:}

The Raj remains central to the British colonial history and an epitome of the western sabotage of the Orient. As Kiernan puts it: "in the history of modern empires the British have for the most important place and in the British empire India" (1969/2015, p. 19). This grand rule has inspired many proBritish and anti-British works that aim either to idealize or demonize the imperialist role of the English. Thus, history provides two different pictures of the British colonial rule in India. This chequered nature of the historical narratives has been termed as the "historiographical game" (1973, p. 277) by White. The conflict further confirms the argument of the new historicists who are "determinedly suspicious of unified, monolithic depictions of cultures or historical periods" (Payne, 2005, p. 3). But leaving the "contradictory "histories" (Selden et al, 2007, p. 191) aside, the episode puts an unmistakable mark on the consciousness of both the colonizer and the colonized.

Denis Judd's (2004) anecdotal narration of the history of the English rule in India is a precise and interesting one. He surveys the development and sustenance of it by managing "sharply different ways of seeing the experience" (p. 191). Equipped with the claimed pluralist methodological and conceptual tools, he also attempts to resolve certain "big and complex questions" (p. 191) that problematize the history of the reign stretched temporally across "350 years" (p. 200). Throughout the text, his approach is glaringly marked by predilection towards the orientalist position. For example, being a voice of the colonizers, he reduces the cruel crumbling of the civilizational fabric of India to mere "interaction" (p. 200) between the English and Indians. However, it provides an informative narrative of the progression and collapse of English imperialism in the subcontinent.

The postcolonial writers have also aptly recorded their remonstrance regarding the unjust usurpation of the Indian Territory, civilization, and resources. From the perspective of the anticolonial rhetoric, Tharoor's (2017) is one of the latest and authentic critiques of the British pillages of India. Imbued with the anticolonial passion, his work indicts the imperialist British government of prosecuting unprecedented exploitative strategies to evacuate India of all the treasures it preserved since times immemorial. 'Loot' is the key term in his exposition of the villainy of the English Empire:

And the vast sums of Indian revenues and loot flowing to England, even if they were

somewhat less than the billions of pounds Digby estimated, provided the capital for

British industry and made possible the financing of the Industrial Revolution. (2017, p. 56)

His primary focus is on the financial drainage from the colony to the center. To prove his thesis, he has empirically explained the systematic plunder of the colony's possessions by the colonizers. Besides expounding his points cogently, he keeps on rejoining the delusive discursive gimmicks of the apostles of the empire who present the British as benevolent and assuage their loot. Summarily, with his impressive idiom and authentic arguments, he has aptly exposed the inglorious Empire.

Parallel to the historical writings, the fictional ones have also proliferated and, also, received the critical attention of the theorists. They have been labeled as "the fictions of empire" (Parry, 2004, p. 107) that include the mutiny fiction produced concerning the Indian revolutionary war of 1857. These fictions constitute the "allegory of empire" (Suleri in Ashcroft et al., 1995, 111) and provide insights into the debates revolving around innumerable issues resulting from the British colonization of India. Due to the significance of these fictions in understanding politics, Said dubs it as the "novelistic institution" (1994, p. 71).

One of the most visible coercive textual strategies of the colonial fictions is to push the indigenous inhabitants to the invisible periphery and make the colonizers tower in the center. Naik's study (1991) exposes the indifference of "British novelists writing on India" (p. 75) who narrate without showing any consideration for the Indians or their civilization. His article provides an enthusiastic stricture of "the notorious British insularity" (p.89) about the Indians. He has criticized the haughty position of the English indifferent narrators who evacuate, in their fictional world, India from all that is indigenous: culture, religion, language, etc. This reductionist technique is key to understanding colonial rhetoric.

The most inclusive compendium of the critical analyses of the English novels on the issue of the Indian mutiny is Chakravarty's (2004). He approaches "the literary yield of the rebellion" (p.1) written by the English novelists, the "seventy" (p. 3) novels. He has identified "the network of plots, 
redactions, myths, politics, and cultures that contributed to and sustained the British view of the events between1857and1859" (p. 181). The critique presents a holistic version of the English reflections on the Mutiny by culling the scattered representations in all the seventy novels. However, he has willingly eschewed the Indian novels in English on the topic and exclusively elaborated the English ones.

The representational politics is pervasive in the English writings of the colonial period to the extent that even the innocent novelists have been found to indulge, consciously or unconsciously, in the promotion of the orientalist and imperialist agendas. Said explains the counter-intuitive connection between "Jane Austen and Empire" (1994, p. 80). The imperialist predilections of the other ostensibly apolitical writers have also been exposed by using the Saidian strategy of contrapuntal readings: Henry (2002) exposes Eliot's "intimate involvement with the empire" (p. 149), Allen and Trivedi (2000) read Dickens' "A Tale of Two Cities [1859] in the context of the 'mutiny' of 1857" (p. 58). These re-readings of the canonical writers are startlingly informative and enlightening. The instances can easily be multiplied to evidence the relationship between the apolitical fiction writers and covertly political agendas of the empire. Besides these, many other studies of the fictions of empire are available: Brantlinger (1990), Paxton (1992), Sen (2007), Lakshmi (2007), Joshi (2007), Christopher Herbert (2008), and others. The critics from both sides, the center and the colony have opined about the nature of these combative fictions. In short, all these works contribute to establishing the significance of the sub-genre by explaining various aspects of the novels.

Consequently, the response to the Mutiny/ War of Independence is conditioned with the attitude towards the status of the British colonial control of India. The pro-empire historians look at the Mutiny as an act of unwarranted defiance to hinder the progression. For example, Gregory Fremont-Barnes (2007) terms the mutinous endeavors as "exceptional brutality" (p. 7). Contrariwise, the anticolonial writers present the revolution to be the desired act, the "heroic effort" (Chandra et al, 1987, p. 1), to end the undesired colonial rule. The same dichotomy is visible in the literary rendering of the Raj and the revolution against it. Thus, both perspectives have received forceful enunciation by a host of writers, historians, and litterateurs, and promulgated intriguing and rich literature.

\section{Contrasting Representations in Tracy and Naikar's Novels:}

Tracy and Naikar have delineated details of the rebellious event of 1857 in their respective novels. But their representations of the happenings are in absolute contrast with each other and provide a consummate instance of the polemical mode of narration. Both of these novels unambiguously conform to the norms of the broader categories to which they belong, colonial discourse and postcolonial counter-discourse. The different points of departure, where the novelists contradicted each other, have been explained below to make explicit the fickle nature of the textual narratives.

The prime moot point is that of establishing or challenging the legitimacy of the empire. The colonizers, as represented by Tracy, present the colonization as an act of benevolence by the English because they have generously left the bounteous West with the aim to rescue the decaying domain of India. Tracy has averred the generosity of the British who descended into the obnoxious territory to accomplish their humanitarian agendas. The aim of their sojourn is "to leaven the decaying East" (1907, p. 317). Their avatar in India under missionary pretext makes them appear like "gods among the Asiatic scum" (Tracy, 1907, p. 245). The gist of this hyperbolic rendering is to scaffold the colonial enterprise by declaring it an offshoot of the philanthropic ideals of the English people and negate the presence of any materialist agenda behind it. The English have come, according to Tracy, to rescue the Indians who are living under the primeval predicament.

The counter discursive response to this attempt of legitimization of the colonial project of the English has been presented by Naikar who disrupts the rhetoric of humanitarianism and exposes the exploitative practices of the purveyors of usurpation. He rebuts the verbal chicanery of the English writers who struggle to justify the Raj. He declares them to be "foreign rulers" (2001, p. 18), rather "alien [a more pejorative word] rulers" $(2001$, p. 25), who "came to this country under the pretense of carrying on trade" (Naikar, 2001, p. 52). They have no justification for their unjust capture of the Indian land. His protagonist, Bhaskararao Bhave, voices zealously the anti-colonial stance of the Indians: "I refused to be governed by the alien law" (Naikar, 2001, p. 215). So, Naikar negates colonizers' rhetoric of legitimacy of the imperialist expansion and stresses that the Raj has no room in the Indians' collective cult of unconditional liberation. 
This conflict over the issue of the legitimacy of the British rule is the central conflict of the colonizer/colonized dialogue. The English novelists of the Empire, as represented by Tracy, present colonialism as a protective endeavor of the center to patronize the periphery. They contrive the contours of the colonial projects to make them appear as the desirable philanthropist programs. Contrary to the imperialists' approval, the Indians, as voiced by Naikar, portray it as mere pillage of the indigenous people. They disrupt the humanitarian veneer of the colonial power and expose their looting strategies.

The contentious status of the revolutionary struggle against the colonial government is a logical consequence of the controversy over the establishment of the colony. The British imperialists condemn the rebellion unequivocally and declare it to be an utterly unwarranted one. Equally unequivocal in approval of the revolution, the Indians stress the desirability of the defiance against the illegitimate colonial rule. Tracy (1907) has subjected the Indian rebels to the strident strictures for their vicious attempt to avert the prosecution of the enlightenment project. He pejoratively denominates the struggle as mutiny in the subtitle of the novel. This pejorative parlance is maintained throughout the text as he keeps on describing the Indian struggle in a derogatory manner: "inconceivable folly" (p. 41), "disastrous upheaval" (p. 95), "the crime" (p. 325), "ordered treachery" (p. 110), and numerous other demonizing qualifications. All these hyperbolically aggressive descriptions contribute to portray the conflict as a "useless and horrible war" (p. 267).

The Indian response to the British disapproval of the revolution is pertinently present in Naikar's novel. Countering the pejorative nomenclature of the imperialists, he entitles the defiance in a laudatory manner: "the first war of independence" (2001, p. 63), "war of freedom" (2001, p. 63), and the "righteous war" (2001, p. 64). The revolutionaries have been presented as the champions of liberation who struggle to make their land free from the "exploitative policies" (Naikar, 2001, p. 111) perpetuated by the imperial system. They are not the marauding mutineers but instead the freedomfighters who endeavor for "the noble purpose" (Naikar, 2001, p. 233) that is regulating their "patriotic fight" (Naikar, 2001, p. 233). Naikar ratifies the resistance of the revolutionaries to challenge the rule of East India Company, the surrogate for the British Raj. So, the military retaliation by the revolutionaries is merely an unwanted Mutiny for the English, whereas it remains the auspicious War of Independence for the Indians. The roots of the contrasting representations are to be found in the nationalist positions and ideological preferences.

Characterization is another disputed aspect that generates conflictual representations of the self and other. The supercilious disposition of the British marks Tracy's narrative. He portrays the British characters with a laudatory touch to show them as apt representatives of humanitarian power. To make the best of these characters conspicuous, he cleverly creates the detestable Indians who work as foils to them. Thus, the "the legendary heroes" (1907, p. 53) and "the unconquerable" (Tracy, 1907, p. 233) English soldiers have been juxtaposed with the Indians who appear as "the human locusts" (Tracy, 1907, p. 254), "slayers of women and children" (Tracy, 1907, p. 312), "untamed savages" (1907, p. 54), and "predatory class" (Tracy, 1907, p. 22). These portrayals invoke respect for the heroic English and provoke disgust for the villainous Indians.

Contrary to Tracy's portrayals, Naikar idealizes the Indian characters and lambasts the English ones. The "heroic and adventurous" (2001, p. 19) Indians have been shown fighting under the leadership of a "dauntless king" (Naikar, 2001, p. 216), Bhaskararao Bhave, who epitomizes the grandeur of the nation. Moreover, the character of Nanasaheb has been portrayed positively throughout the text. He has been vilified by Tracy but eulogized by Naikar. The collective good of the Indian race has also been stressed: "Brahmins are kind by nature is very true" (Naikar, 2001, p. 219). Parallel to the positive portrayal of the Indians, he keeps on bashing the British characters. These "British monsters" (2001, p. 192), "red-faced monkeys" (Naikar, 2001, p. 29), and "Anglian raksasas" (Naikar, 2001, p. 64) have been presented as the killers of the "innocent people" (Naikar, 2001, p. 91). Thus, the binary created by Tracy has been reversed to propose the goodness of the Indians and the evil nature and practices of the British. So, both, the English and the Indians create binaries to proffer the stereotypical representation of an idealized Self and demonized other.

The discursive manipulation is not limited to the portrayal of human characters, rather the representation of the spatial and environmental dimensions of India precipitates another contrast between the novels. Tracy visualizes India as a wasteland without any kind of natural bounties. The 
situation is aggravated, according to him, because of the absence of the civilizational nurturing of the available natural resources. The awful Indian heath stretches marked by the repulsive strangeness:

On such a night all India seems to be dead as a land but tremendously alive as a storehouse of insects, animals, and reptiles. Even the air has its strange denizens in the guise of huge beetles and vampire-winged flying foxes. (Tracy, 1907, p. 194)

The Indian ambiance has been evacuated from the human presence and turned into a place swarming with eerie denizens that instigate the sense of abhorrence. It is a strange reduction of the populous society of India to mere moor stretching without the civilizational touch. In this unwelcoming colony, the milieu is highly problematic for the British soldiers who find its scorching atmosphere unbearable because they are accustomed to the soothing seasons of their native land. Tracy contrast the British morning with that of India:

A May morning in Punjab must not be confused with its prototype in Britain. Undimmed by cloud, unchecked by cooling breeze, the sun scorches the earth from the moment his glowing ray's first peep over the horizon. (1907, p. 41)

The lusciousness attributed to morning is absent in India and it torments the British soldiers. They are accustomed to the soothing morning breezes of their native land, England, and find it difficult to adjust to the unpleasant atmosphere of the Indian locality.

The colonizer's version of the non-human phenomena of the colony has been re-joined with a positive delineation of it by the postcolonial writers. Naikar, being the native novelist, depicts the spatial dimensions of India with a touch of patriotic affinity. Here, India becomes majestic giving a "grand look" (2001, p. 1). The prototypical pastoral surrounding where "the purple and rosy clouds" are "slowly drifting in the eastern sky" (Naikar. 2001, p. 45) has been envisaged. Naragund, the kingly state being managed by Bhaskararao Bhave, epitomizes all the scenic beauties with its "regaling wind" where the cuckoos "cooing melodiously" (Naikar. 2001, p. 45). In sharp contrast to Tracy's representation of the Indian morning, Naikar's India has to revitalize the "fresh breeze of the morning" (Naikar, 2001, p. 38). Hence, Naikar paints India with brighter color to disrupt the black blanket put on it by the English writers like Tracy. The crystal clear contrast between depictions of the territorial dimensions of India bespeaks the extent of the discursive constructionism that triggers the textual representations.

Furthermore, being polemical, the narratives make full use of the rhetorical chicanery to scaffold the ideological content communicated under the aesthetic veneer. The novelists have made extensive use of the discursive strategies and gimmicks to legitimize the respective stances. These combative fictions heavily rely on the fallacious rhetoric for communication of the desired themes. Tracy artistically uses verbal trickeries to create the desired effect. For example, referring to the various reports of the event, he dubs the Indian one as the "native rumour" (1907, p. 262), implying fickleness, and the British one as the "true history" (1907, p. 262), implying authenticity. Another assuaging strategy has been used while describing the details of the war, that is, the English "retreat" (Tracy, 1907, p. 50) when pressed but the Indians have shown to have "fled" (Tracy, 1907, p. 59) from the battle. The same strategy continues regarding the expression of the religious zest and the English have been attributed the "religious enthusiasm" (Tracy, 1907, p. 311), whereas the Indians exhibit the "religious fanaticism" (Tracy, 1907, p. 21). The text is replete with this kind of discursive strategies and narrative ploys.

Naikar, being a postcolonial writer, is wide awake to the poignant impact that the rhetorical strategies can generate. He makes apt use of various discursive gimmicks to assuage the defeat of the Indian rebels by concentrating the ethical perspective of the conflict instead of the practical one, that is, he attempts to diminish the English superiority on moral grounds. Likewise, he organizes conservatism of the Indians as the red herring fallacy to divert attention from the social backwardness. Moreover, throughout the text, he eschews stories of the submissive Indian kings and foregrounds only the defiant ones. However, the peripheral deserters have been concentrated who succumb to the mercenary impulse and surrender to the British. This strategy of the skewed narration has the obvious implication of suggesting the revolution to be a collective endeavor of the Indians against the British colonizers. Finally, there is a recurrent use of the fallacious argument of appeal to emotion, that is, the production of the sentimental discourse regarding the religious issues and promiscuous behavior of the red coats to the indigenous females. Thus, explication of the text evinces the presence of various discursive strategies and verbal trickeries for generating an impressive discourse. The English 
struggled to justify their colonial control and the Indians have used chicaneries to produce the counter-discursive argument to dismantle the orientalist metanarrative embedded in the colonial fiction.

Another important contrast is to be noticed about the response to the post-mutiny conditions. The British colonizers and the indigenous Indians have opposing views on the issue. For the British, the failure of the revolution is a blessing as it entails the formal annexation of the colony with Great Britain. They claim to have brought "prosperity out of all comparable reckoning" (Tracy, 1907, p. 326) after the official takeover. Contrariwise, the catastrophic failure ensues assortment of the tragic consequences for the miserable Indians whose kings have been made beggars (Naikar, 2001, p. 206) and the masses may be killed or arrested by the British soldiers "any time for any or no reason" (Naikar, 2001, p. 213). In this way, the result of the revolution means prosperity for the English and pulverization for the Indians.

In short, due to the essential opposition between the colonizer English and the colonized Indians, the count of the contrasts can be multiplied: the religious antagonism between the Christian English and the Hindu/ Muslim Indians, characterization of the nymphomaniac females by the respective groups, the issue of mutual vulnerability, and so on. The texts are replete with conflictual perspectives and the outlined dichotomies are only the representative examples to explain the confrontational textures of these novels. The selected novels of the revolutionary war are imbued with the belligerent perspectives of nationalist ideologies. Revolving around the central conflict of the rebellion, different other orientalist and postcolonial perspectives find their way into the fictional discourses: the parochial stereotyping, political projections, ideological slogans, and racist rhetoric. Summarily, the argumentative narrative mode deliberately adopted for both novels is marked by parochialism that bespeaks gimmickries of the discursive (miss) representations.

\section{Conclusion:}

The comparative analysis of the selected narratives has brought forth a succession of representational contrasts and historical controversies vis-à-vis the event, the mutiny/ revolution, and the participants, the mutineers/ revolutionaries. The researchers have located these novels into the discursive continuum of colonial and postcolonial paradigms to draw the comparison and propose the interpretation. The polemical disposition of the fiction has been explained by identifying the glaring contrasts between both versions.

The English stance about the rebellion, coupled with the broader orientalist discursive constructions, has been represented by Tracy with fidelity. In his novel, the Mutiny, the pejorative nomenclature itself symptomatic of the stance, appears as an unpardonable blunder whose redemption is sought in the perpetuation of the Raj. In continuation of the prototypical orientalist rhetoric, Tracy has deified the English who have descended from the Western firmament into the Indian hades to enlighten it with their luminous halos. The strategy of characterization of the villainous Indians has further expanded the unbridgeable chasm between the auspicious image of the English and the detestable indigenous people. Resultantly, the failure of the mutinous movement has been represented as the foundational factor towards the prosperity of the Indian masses as it fortifies the British patronage of the colony. Moreover, the theme of going native, deterioration of the civilized English soldiers due to their exposure to the savage natives, has also been incorporated in the text. Compositely, the novel is marked by the imperialist pride, discursive degeneration of India, religious prejudice, fallacious argumentation, reductive narration, and silencing of the indigenous people.

Contrary to Tracy's representation, Naikar comes with the aim of vindication of the revolutionary struggle that is considered a laudable move to coup the illegitimate rule of the English over India. In his version of the colonial encounter, the orientalist stereotypes have been reversed, that is, the Western colonizer becomes villainous and the indigenous Indians have been eulogized for their uprightness. The British soldiers have been shown as monstrous beings who massacre innocent natives merely to sustain their unlawful capture of the Indian land and resources. Moreover, the Indian social structure has been presented proudly to counter the misrepresentations floated by the imperialist writers and the religious hatred reciprocated zealously. Ultimately, the quelling of the revolutionaries by the British has been represented as an epic catastrophe as it entails the more coercive colonial clutch. In short, all the narrative chicaneries and discursive strategies have been used to accomplish the disruption of the colonial discourse. 
To sum up, Tracy and Naikar's textual representations of the historical event of 1857 mutiny/revolution embody what John Limon has termed as "a competition of histories" (1994, p. 30). Both of them have toed their nationalist path and, to adapt K.K. Aziz's words, "their view of history is made up of principle forgetfulness, willed oblivion, and purposeful silence. (1993, p. 247). They have produced the desired versions following their national preference which cannot be simultaneously true as they stand in diametrical opposition to each other. The comparative analysis of these combative fictions facilitates understanding the intriguing discursive manoeuvrings cocooned under the sincere mimetic simulations. Coalescing of narration with nationalism, an amalgamation of factual details with fabricated ones, and a confluence of aesthetics with politics - all these chicaneries have been exposed to explain the parochial underpinning of these historical fictions.

\section{References}

Ashcroft, B., Griffiths, G., \& Tiffin, H. (Eds.). (1995). the post-colonial studies reader. Routledge.

Ashcroft, B., Griffiths, G., \& Tiffin, H. (Eds.). (2007). Post-colonial studies: The key concepts. Routledge.

Aziz, K. K. (1993). The murder of history: A critique of history textbooks used in Pakistan. Lahore: Vanguard.

Aziz, K. K. (2009). The making of Pakistan. 1977. Lahore: Sang-e-Meel publication.

Brantlinger, P. (1990). Rule of darkness: British literature and imperialism, 1830-1914. Cornell University Press

Chakravarty, G. (2004). The Indian Mutiny and the British imagination. Cambridge University Press.

Chandra, B., Mukherjee, M., Mukherjee, A., \& Panikkar, K.N. (1987). India's Struggle for Independence. UK: Penguin.

Chandra, N.D.R. \& Prasad, N.K. (Eds). (2010). the Works of Basavaraj Naikar: Critical Perceptions (2 Vols). New Delhi: Sarup Book Publishers,

Fremont-Barnes, G. (2007). The Indian Mutiny 1857-58. Oxford: Osprey Publishing.

Henry, N. (2002). George Eliot and the British Empire (Vol. 34). Cambridge University Press.

Herbert, C. (2008). War of no pity: the Indian Mutiny and Victorian trauma. Princeton University Press.

Jeyaraju, M. A. (2006). 'Rehabilitation of an Indian Nationalist Hero in Basavaraj Naikar's Novel: The Sun Behind the Cloud'. In Dodiya, J. (pp. 278-287) Perspectives on Indian English Fiction, 278.

Jørgensen, M. W., \& Phillips, L. J. (2002). Discourse analysis as theory and method. California: Sage.

Joshi, P. (2007). Mutiny Echoes: India, Britons, and Charles Dickens9s A Tale of Two Cities. NINETEEN-CENTURY LITERATURE, 62(1), 48-87.

Judd, D. (2004). The lion and the tiger: the rise and fall of the British Raj, 1600-1947. Oxford University Press.

Kiernan, V. (2015). The lords of humankind: European attitudes to other cultures in the imperial age. 1969. London: Zed Books Ltd.

Lakshmi, A. (2007). The Mutiny Novel: Creating the Domestic Body of the Empire. Economic and Political Weekly, 1746-1753.

Lane, R. (2006). The postcolonial novel. UK: Polity.

Limon, J. (1994). Writing after the war: American war fiction from realism to postmodernism. Oxford University Press.

Misra, C. (2016) Rewriting History through Drama: A Study of Naikar's A Dreamer of Freedom. Indian Scholar Vol. 3 Issue I, 196-200.

Naik, M. K. (1991). On the Ignorance of the Learned British: An Aspect of Anglo-Indian Fiction. Indian Literature, $34(5$ (145), 75-93.

Naikar, B. (2001). The sun behind the cloud. New Delhi: Atlantic Publishers and Distributors.

Parry, B. (2004). Postcolonial studies: A materialist critique. Routledge.

Paxton, N. L. (1992). Mobilizing chivalry: Rape in British novels about the Indian uprising of 1857. Victorian Studies, 36(1), 5-30.

Ramone, J. (2011). Postcolonial theories. Palgrave Macmillan.

Said, E. (1994). Culture and Imperialism. 1993. New York: Vintage.

Said, E. W. (1995). Orientalism: western conceptions of the Orient. 1978. USA: Penguin. 
Sarangi, J. (Ed). (2008). Basavaraj Naikar: Trends. New Delhi: Authors Press.

Sarangi, J. (Ed). (2009). The Voice of India: Critical essays on Basavaraj Naikar. New Delhi: Authors Press.

Sen, I. (2007). Inscribing the Rani of Jhansi in Colonial 'Mutiny' Fiction. Economic and Political Weekly, 1754-1761.

Singh, S. D. (1973). Novels on the Indian Mutiny. Arnold-Heinemann India.

Singha, S.P. (Ed). (2006). Perspectives on Basavaraj Naikar. Ahmedabad: Shanti Prakash.

Tharoor, S. (2017). Inglorious Empire: What the British Did to India. UK: Scribe Publishers.

Tiffin, H. (1987). Post-colonial pieces of literature and counter-discourse. Kunapipi, 9(3), 4.

Tracy, L. (1907). The Red Year: A Story of the Indian Mutiny. New York: Grosset \& Dunlap Publishers.

Trivedi, H., \& Allen, R. (Eds.). (2000). Literature and Nation. London: Psychology Press.

Wenden, A.L. (2005). "The politics of representation: a critical discourse analysis of an Aljazeera special report". In International Journal of Peace Studies, Volume 10, Number 2.

White, H. (1973). Metahistory: The historical imagination in nineteenth-century Europe. USA: John Hopkins University Press.

White, H. (1987). The content of the form: Narrative discourse and historical representation. USA: John Hopkins University Press. 